manures. The variations in drawbar pull figures are also closely related to the amount of drainage and to the early stages of plant growth.

It is found that the drawbar pull is comparatively unaffected by speed of cultivation. Thus for tractor ploughing, an increase from $2 \frac{1}{2}$ to 4 miles per hour, which would mean a 60 per cent. greater area ploughed in a given time, only involves a 7 per cent. increase in drawbar pull. It is improbable that the cost of the extra fuel necessary to give this increased pull would be more than a small fraction of the saving in labour costs due to increased speed of work. The design of tractors run at higher speeds without undue wear and tear, and of implements to perform satisfactory work at high speeds, should present no insuperable difficulties.

\title{
The Geology of the New Mersey Tunnel.
}

\section{By Prof. P. G. H. Boswell, University of Liverpool.}

$\mathrm{O}^{\mathrm{N}}$ N December I6 H.R.H. Princess Mary inaugurated the work of excavation for the new tunnel under the River Mersey, sanctioned by Parliament last August. As is well known, a railway tunnel of invert form and $26 \mathrm{ft}$. in width has long been in existence; it was begun in $\mathrm{I} 88 \mathrm{I}$ by the Mersey Railway Company and completed some years later. The new tunnel is to be a highway and will be the largest of its kind. The major part of the tube will be circular in section, with an internal diameter of $44 \mathrm{ft}$., the road-way being constructed so as to take fullest advantage of the width. It will thus provide a four-way road for slow and fast two-way traffic, with side-walks of about $4 \mathrm{ft}$. for purposes of traffic control, etc. The cost of the tunnel is to be $4,750,000 l$, , half of which will be provided by the Ministry of Transport in view of its highway character.

The line of the tunnel is to be roughly parallel to and about I 50 yards north of the existing tunnel, its direction being about N.E.-S.W. The total length of tunnel will be rather more than two miles, of which about three-quarters of a mile will lie beneath the river.

At the Birkenhead end the entrance is to be near the Birkenhead Woodside Railway Terminus, and thus close to the docks. A suitable gradient of $\mathrm{I}$ in 30 will be obtained by a spiral descent. On the Liverpool side the tunnel will bifurcate, the northern branch ascending by a spiral gradient of $\mathrm{I}$ in 30 to the docks north of the pier-head, and the southern branch by a fairly straight stretch, of gradient $\mathrm{I}$ in 20 , to an entrance in the heart of the city.

Throughout its course the tunnel will lie in Triassic sandstone and the overlying glacial deposits. On the Birkenhead side, under the River Mersey and for about $55^{\circ}$ yards from the dock-walls on the Liverpool side, the rock belongs to the Middle Bunter Sandstone (or "Pebble-beds," though pebbles are scarce in the district). The beds dip at a low angle eastwards. The last $33^{\circ}$ yards of the southern branch on the Liverpool side may be expected to lie in the Upper (Soft) Mottled Sandstone of the Bunter, which is here thrown down by a fault against the Middle Sandstone.

The latter is a firm, well-bedded rock, excellent for purposes of excavation, for it will stand well; the Upper Sandstone is rather soft. Both rocks, however, are renowned for the copious water-supply yielded by them.

It will be remembered that the Mersey estuary narrows considerably where Birkenhead and Liverpool are situated. Indeed, a rock-bar is responsible for the consequent ease of communication between those ports. Higher up the river, the overburden of glacial drift thickens, and, as the late T. Mellard Reade demonstrated, a deep channel of drift occurs at Widnes. As a result of his study of minor channels of drift in the area of the Liverpool and Birkenhead docks, Mellard Reade declared, before the Mersey railway tunnel was cut, his belief that they drained into the main buried channel, which would thus extend down the Mersey estuary, through the rock-barrier to the sea. He claimed, with good reason as the sequel showed, that geologists could previse, and warned the engineers that the channel of drift must be expected in the course of their operations. The channel was struck on the down-grade portion of the tunnel about 90 yards from the Liverpool side, and $44 \mathrm{ft}$. below the present bed of the Mersey, its base being closely $95 \mathrm{ft}$. below O.D. An unavailing attempt was made to avoid it, but fortunately the lowest $6 \mathrm{ft}$. of the channel (which was cut into for a length of about 66 yards) proved to be a stiff purple Boulder Clay. This clay yielded an excellent roof, and, unlike the sandstone, gave no trouble from water.

Another prediction, even more puzzling to those to whom the geology was not familiar, was that of the late G. H. Morton of Liverpool, who drew a geological section across the Mersey estuary and inferred the presence of a north-south fault with a westerly downthrow, under the bed of the river. This fault was struck in due course near the place assigned to it by Morton.

Trial-borings in the roof of the railway tunnel under the middle of the river proved a thickness of at least ${ }_{5} \mathrm{ft}$. of Bunter Sandstone. The level of the top of the new tunnel in the part beneath the river will be nearly the same as that of the existing tunnel (approximately I06 ft. below O.D.). With the information made available by Mellard Reade and Morton, and the precision given to it by the excavations for the railway tunnel, and with the knowledge which has accumulated since (the officers of H.M. Geological Survey having re-surveyed the area just before the War), the engineers of the new enterprise will be fully forewarned of possible difficulties. But nobody, least of all a geologist, would care to predict the exact course, changes in depth, or lithological variation from clay to sand or gravel in a buried channel of glacial drift. There is no reason to doubt, however, that the new undertaking will prove successful. 